\title{
PENINGKATAN HASIL BELAJAR PESERTA DIDIK DENGAN PENERAPAN MODEL PEMBELAJARAN PROBLEM SOLVING BERBANTUAN ALAT PERAGA
}

\author{
Arlin Astriyani \\ Universitas Muhammadiyah Jakarta \\ arlin_0717@yahoo.com
}

\begin{abstract}
Abstrak
Penelitian bertujuan untuk menganalisis penerapan model pembelajaran Problem Solving dalam meningkatkan hasil belajar peserta didik. Penelitian ini dilakukan di Program Studi Pendidikan Matematika Universitas Muhammadiyah Jakarta mata kuliah Geometri pada tahun ajaran 2016/2017. Metode yang digunakan dalam penelitian ini adalah Penelitian Tindakan Kelas (PTK) yang dilaksanakan dalam dua siklus. Instrumen penelitian yang digunakan adalah lembar observasi, jurnal harian peserta didik, pedoman wawancara, tes pemecahan masalah matematika, dan dokumentasi. Hasil penelitian mengungkapkan bahwa penerapan model pembelajaran Problem Solving dapat meningkatkan hasil belajar matematika peserta didik. Pada siklus I nilai rata-rata hasil belajar matematika peserta didik 73 meningkat 8,0 menjadi 81 pada siklus II. Selain hasil belajar matematika, aktivitas belajar peserta didik dan respon peserta didik menunjukkan peningkatan. Rata-rata aktivitas belajar peserta didik pada siklus I sebesar 67,5\% dan meningkat $6,1 \%$ pada siklus II menjadi 73,6\%. Berdasarkan jurnal harian, rata-rata persentase respon positif peserta didik mengalami peningkatan, yaitu pada siklus I sebesar 59,2\% meningkat $20,7 \%$ menjadi $79,8 \%$ pada siklus II.
\end{abstract}

Kata Kunci: Hasil Belajar, Problem Solving.

\section{PENDAHULUAN}

Aspek pembelajaran yang paling banyak disoroti adalah hasil belajar siswa. Hasil belajar merupakan pengukuran dan penilaian usaha belajar yang dinyatakan dalam bentuk simbol, angka, huruf, maupun kalimat yang dapat mencerminkan hasil yang sudah dicapai oleh setiap anak dalam periode tertentu. Sekolah-sekolah di tanah air tentunya sudah mempunyai pengalaman yang cukup lama dalam penerapan mata pelajaran matematika di sekolah. Namun, dilihat dari hasil belajar yang diperoleh siswa, ternyata hasil yang dicapai masih jauh dari memuaskan. Melihat kondisi seperti ini, maka perlu adanya upaya untuk meningkatkan dan memperbaiki hasil belajar siswa khususnya hasil belajar matematika. Pada 
dasarnya banyak faktor yang dapat menyebabkan hasil belajar siswa rendah. Salah satu faktor tersebut adalah model pembelajaran. Penggunaan model pembelajaran yang tepat dapat mendorong tumbuhnya rasa senang siswa terhadap pelajaran, menumbuhkan dan meningkatkan motivasi dalam mengerjakan tugas, memberikan kemudahan bagi siswa untuk memahami pelajaran sehingga memungkinkan siswa mencapai hasil belajar yang lebih baik. Ahmad dan Zanzali (2006: 7) dalam penelitiannya menyimpulkan bahwa seharusnya di dalam proses belajar mengajar matematika di kelas digunakan pendekatan alternatif yang membuat siswa berkesempatan untuk mengajukan masalah. Lee (2010: 12) dalam penelitiannya menyimpulkan bahwa kemampuan siswa dalam memecahkan masalah meningkat setelah diberikan pembelajaran Problem Solving. Xia et al. (2008: 154) juga menyatakan bahwa pembelajaran yang melibatkan aktivitas Problem Solving dapat menimbulkan ketertarikan siswa terhadap matematika, meningkatkan kemampuan mereka dalam mengajukan masalah dan meningkatkan kemampuan belajar matematika mereka dengan baik. Dalam proses pembelajaran di kelas, diharapkan tenaga pengajar dapat menerapkan model pembelajaran yang sesuai dengan materi dan dapat membuat siswa berperan aktif dalam kegiatan belajar mengajar di kelas.

Proses belajar mengajar matematika di kelas digunakan pendekatan alternatif yang membuat peserta didik berkesempatan untuk mengajukan masalah. Selain itu, penting untuk tenaga pendidik mengajarkan kemampuan memecahkan masalah sehingga dapat mengantarkan peserta didik mengalami kesuksesan di masa depan dengan menjadi pemecah masalah yang efektif. Dalam proses pembelajaran di kelas, diharapkan tenaga pendidik dapat menerapkan model pembelajaran yang sesuai dengan materi dan dapat membuat peserta didik berperan aktif dalam kegiatan belajar mengajar di kelas. Model pembelajaran yang dapat digunakan sala satunya yaitu Problem Solving.

Rumusan masalah penelitian ini adalah:

1. Apakah penerapan model Problem Solving dapat meningkatkan kemapuan peserta didik dalam menyusun soal cerita?

2. Bagaimanakah aktivitas belajar matematika peserta didik selama penerapan model Problem Solving?

3. Bagaimanakah tanggapan peserta didik selama penerapan model Problem Solving?

Problem Solving merupakan suatu proses mental dan intelektual dalam menemukan masalah dan memecahkan berdasarkan data dan informasi yang akurat, sehingga dapat 
diambil kesimpulan yang tepat dan cermat. Dengan fokus pada Problem Solving maka matematika sebagai alat dalam memecahkan masalah dapat diadaptasi pada berbagai konteks dan masalah sehari-hari. Selain sebagai "alat" untuk meningkatkan pengetahuan matematika dan membantu memahami masalah sehari-hari, maka Problem Solving juga merupakan cara berpikir (way of thinking). Dalam perspektif terakhir ini maka Problem Solving membantu kita meningkatkan kemampuan penalaran logis. Terakhir, Problem Solving juga memiliki nilai aestetik. Problem Solving melibatkan emosi/afeksi siswa selama proses pemecahan masalah. Masalah Problem Solving juga dapat menantang pikiran dan bernuansa teka-teki bagi siswa sehingga dapat meningkatkan rasa penasaran, motivasi dan kegigihan untuk selalu terlibat dalam matematika.

Memahami masalah merujuk pada pemahaman terhadap apa yang diketahui, apa yang ditanyakan, atau apa yang harus dibuktikan dalam suatu soal. Membuat rencana merujuk pada pembuatan model matematika dari soal yang diberikan. Melaksanakan rencana merujuk pada penyelesaian model matematika yang telah disusun. Sedangkan menelaah kembali berkaitan dengan penulisan hasil akhir sesuai permintaan soal. Berdasarkan teori, argumen dan pendapat para ahli tersebut di atas, maka dalam penelitian ini, Problem Solving mempunyai pengertian sebagai proses pembelajaran yang menuntut siswa untuk menyelesaikan masalah, dimana problem yang harus diselesaikan tersebut bisa dibuat-buat sendiri oleh pendidik dan ada kalanya fakta nyata yang ada di lingkungan kemudian dipecahkan dalam pembelajaran di kelas, dengan berbagai cara dan teknik. Model Problem Solving ini menekankan pada penemuan dan pemecahan masalah secara berkelanjutan. Kelebihan model ini mendorong siswa untuk berpikir secara ilmiah, praktis, intuitif dan bekerja atas dasar inisiatif sendiri, menumbuhkan sikap objektif, jujur dan terbuka. Selain itu, model Problem Solving juga dapat melatih dan membiasakan para peserta didik untuk menghadapi dan memecahkan masalah secara terampil serta mengembangkan kemampuan berpikir peserta didik secara kreatif. Sedangkan kelemahannya memerlukan waktu yang cukup lama, tidak semua materi pelajaran mengandung masalah memerlukan perencanaan yang teratur dan matang, dan tidak efektif jika terdapat beberapa siswa yang pasif.

Langkah-langkah model pembelajaran Problem Solving adalah sebagai berikut:

1. Menyampaikan tujuan, materi prasyarat, memotivasi siswa dan mengaitkan materi pelajaran dengan konteks kehidupan sehari-hari.

2. Mengorientasikan siswa pada masalah melalui pemecahan masalah dan mengorganisasikan siswa untuk belajar

3. Membimbing penyelesaian secara individual maupun kelompok 
4. Menyajikan hasil penyelesain pemecahan masalah

5. Memeriksa pemahaman dan memberikan umpan balik sebagai evalauasi (Siswono, 2008: 74)

Alat peraga adalah suatu alat yang dapat diserap oleh mata dan telinga dengan tujuan membantu guru agar proses belajar mengajar siswa lebih efektif dan efisien (Sudjana dan Rivai, 2002 :59). Dengan alat peraga, hal-hal yang abstrak dapat disajikan dalam bentuk model-model yang berupa benda kongkret yang dapat dilihat, dipegang, diputar balikkan sehingga dapat lebih mudah dipahami. Dengan demikian, disamping pemilihan model pembelajaran yang tepat, penggunaan alat peraga juga dirasakan perlu untuk pemantapan konsep-konsep matematika terutama pada sekolah menengah, sehingga tujuan dan hasil belajar yang diharapkan dapat tercapai.

Dengan memperhatikan pendapat para ahli mengenai pembelajaran Problem Solving dan juga langkah-langkah model pembelajaran Problem Solving di atas, maka model pembelajaran Problem Solving berbantuan alat peraga dalam penelitian ini adalah sebagai berikut:

1. Guru menyampaikan tujuan, materi prasyarat, memotivasi siswa dan mengaitkan materi pelajaran dengan konteks kehidupan sehari-hari.

2. Sebelum menyampaikan materi, guru memberikan sebuah masalah kepada siswa terkait dengan materi yang akan disampaikan. Masalah yang diberikan guru mungkin saja akan dijawab oleh siswa dengan cara yang berbeda dengan cara yang akan disampaikan oleh guru nantinya.

3. Guru menyampaikan materi seperti biasa, dibantu dengan alat peraga agar konsep yang ingin disampaikan dapat diterima dengan baik.

4. Guru kembali mengajukan masalah sebagai contoh soal untuk dipecahkan, bisa masalah yang pertama kali diberikan di awal atau masalah baru yang akan dipecahkan dengan menggunakan konsep yang telah diajarkan. Dalam hal ini, guru bisa saja menggunakan alat peraga dalam menyajikan masalah, selain itu, siswa juga dapat memecahkan masalah tersebut dengan memanfaatkan alat peraga yang ada.

5. Guru membimbing siswa dalam memecahkan masalah yang diberikan.

6. Guru mempersilahkan siswa untuk menyajikan penyelesaian mereka, bisa saja siswa satu dengan yang lain berbeda dalam cara pemecahan masalah tersebut.

7. Guru memberikan kesempatan kepada siswa untuk bertanya jika ada yang belum jelas.

8. Guru memberikan soal pemecahan masalah sebagai bahan evaluasi untuk siswa. 


\section{METODE PENELITIAN}

Metode penelitian yang digunakan dalam penelitian ini adalah penelitian tindakan kelas, yaitu suatu pencermatan terhadap kegiatan belajar berupa sebuah tindakan yang sengaja dimunculkan dan terjadi dalam sebuah kelas secara bersama (Arikunto, 2007: 3). Metode penelitian tindakan kelas berusaha mengkaji dan merefleksi suatu pendekatan atau strategi pembelajaran dengan tujuan untuk meningkatan proses dan produk pelajaran di kelas.

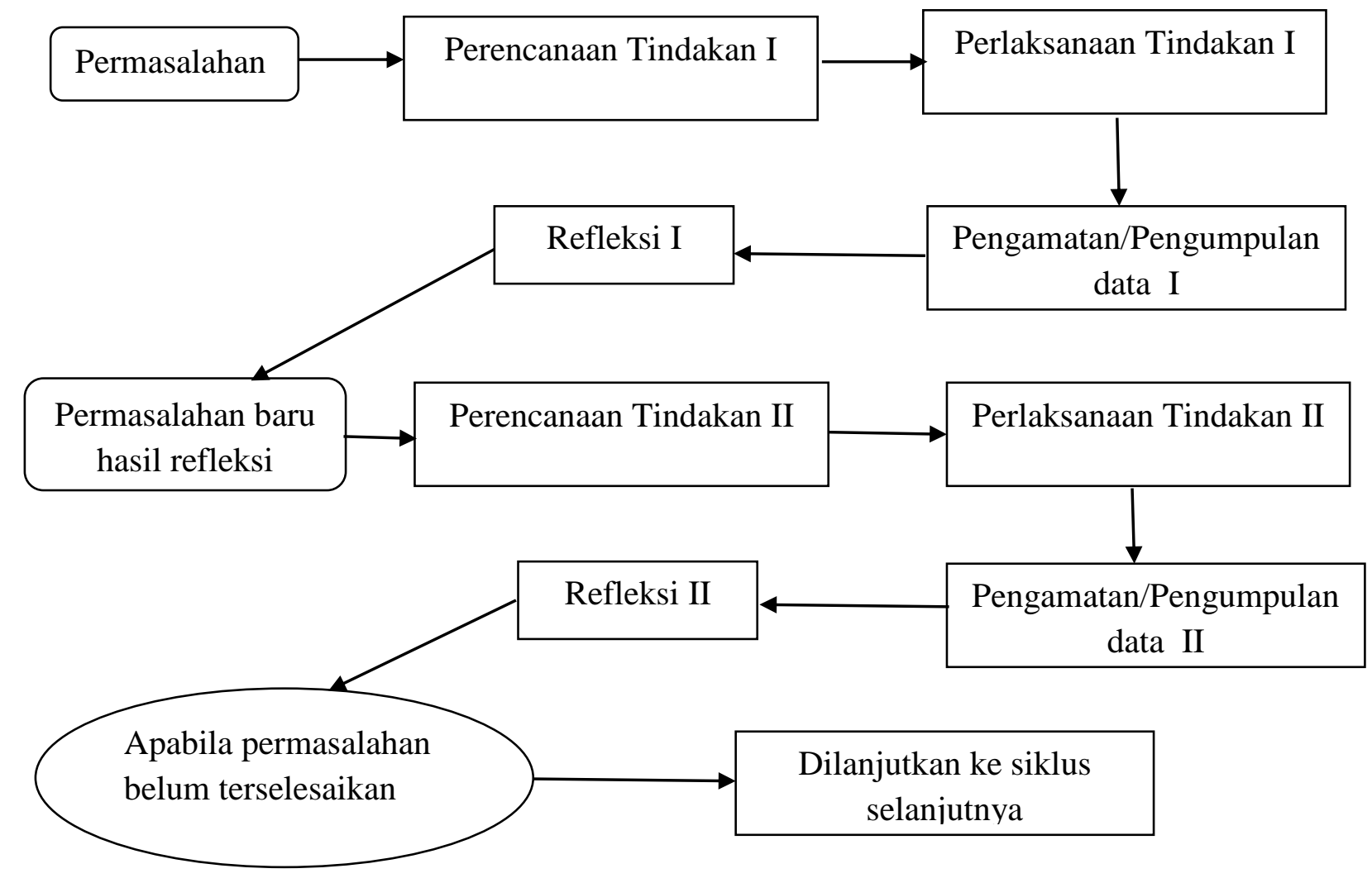

Gambar 1. Desain Penelitian Tindakan Kelas

Penelitian ini dilaksanakan di Program Studi Pendidikan Matematika, Fakultas Ilmu Pendidikan, Universitas Muhammadiyah Jakarta. Penelitian ini dilakukan pada mahasiswa didik semester 1 mata kuliah Geometri tahun pelajaran 2016/2017.

Hasil penelitian yang diharapakan dalam penelitian ini adalah meningkatnya hasil belajar matematika peserta didik. Penelitian ini akan dihentikan jika:

1. Hasil tes kemampuan menyusun soal cerita matematika peserta didik yang diberikan pada setiap akhir siklus menujukkan bahwa nilai rata-rata peserta didik mencapai $\geq 70$.

2. Aktivitas pembelajaran peserta didik $\geq 70 \%$.

3. Minimal $70 \%$ dari seluruh peserta didik merespon positif pembelajaran matematika. 


\section{HASIL DAN PEMBAHASAN}

Peningkatan hasil belajar matematika terlihat dari meningkatnya hasil belajar matematika dari siklus I ke siklus II. Rata-rata nilai peserta didik meningkat 8,0. Pada siklus I nilai rata-rata hasil belajar matematika peserta didik 73 meningkat menjadi 81 pada siklus II. Hasil jawaban peserta didik menunjukkan bahwa hasil belajar matematika meliputi kemampuan memahami masalah, menyusun rencana melakukan perhitungan dan menguji kembali dapat dilakukan cukup baik oleh peserta didik. Berdasarkan peningkatan yang terjadi dan hasil belajar matematika yang diperoleh peserta didik, dapat disimpulkan bahwa penerapan model Problem Solving dapat meningkatkan hasil belajar matematika peserta didik.

Skor rata-rata lembar aktivitas kelompok pada siklus I sebesar 67,5\%. Aspek yang memperoleh skor terendah pada siklus I adalah kemampuan bertukar pikiran. Pada siklus II aktivitas ini meningkat diikuti peningkatan aktivitas-aktivitas lainnya. Skor rata-rata aktivitas kelompok pada siklus II mencapai 73,6\% berdasarkan hasil observasi aktivitas kelompok menunjukkan bahwa penerapan model Problem Solving meningkatkan aktivitas kelompok mahasiswa semester 1.

Respon peserta didik dikelompokkan menjadi tiga kategori, yaitu positif, negatif dan netral. Berdasarkan analisis jurnal harian peserta didik selama siklus I dan siklus II diperoleh terjadi penurunan respon negatif. Rata-rata persentase respon negatif peserta didik turun dari $19,5 \%$ pada siklus I menjadi 6,4\% pada siklus II, sementara itu respon positif meningkat dari 59,2\% pada siklus I menjadi 79,8\% pada siklus II. Berdasarkan hasil rata-rata persentase respon peserta didik yang terdapat pada jurnal harian peserta didik menunjukkan respon positif terhadap penerapan model Problem Solving.

\section{SIMPULAN DAN SARAN}

Berdasarkan hasil penelitian dan pembahasan, disimpulkan bahwa penerapan model pembelajaran Problem Solving dapat meningkatkan hasil belajar matematika peserta didik. Pada siklus I nilai rata-rata hasil belajar matematika peserta didik 73 meningkat 8,0 menjadi 81 pada siklus II. Selain hasil belajar matematika, aktivitas belajar peserta didik dan respon peserta didik menunjukkan peningkatan. Rata-rata aktivitas belajar peserta didik pada siklus I sebesar $67,5 \%$ dan meningkat $6,1 \%$ pada siklus II menjadi 73,6\%. Berdasarkan jurnal harian, rata-rata persentase respon positif peserta didik mengalami peningkatan, yaitu pada siklus I sebesar 59,2\% meningkat 20,7\% menjadi 79,8\% pada siklus II. 
Berdasarkan simpulan, dikemukakan beberapa saran yaitu bagi calon tenaga pengajar hendaknya termotivasi untuk menerapkan model pembelajaran inovatif supaya mampu mengoptimalkan hasil belajar matematika peserta didik terhadap suatu konsep matematika. Salah satu model pebelajaran inovatif yang dapat diterapkan untuk mengoptimalkan hasil belajar matematika peserta didik terhadap konsep matematika adalah model pembelajaran Problem Solving.

\section{DAFTAR PUSTAKA}

Ahmad, S. and Zanzali, N. (2006). "Problem Posing Abilities in Mathematics of Malaysian Primary year 5 Children: An Exploratory Study". Jurnal Pendidikan Universitas Teknologi Malaysia. 1-9.

Arikunto, Suharsimi. (2007). Penelitian Tindakan Kelas. Jakarta: PT Bumi Aksara.

Lee, S. (2010). :The Effect of Alternative Solutions on Problem Solving Performance". Taipei Municipal University of Education. Vol. 1 (1), hal: 1-17.

Siswono, Tatag Yuli Eko. (2008). Model Pembelajaran Matematika Berbasis Pengajuan dan Pemecahan Masalah untuk Meningkatkan Kemampuan Berpikir Kreatif. Surabaya: UNESA University Press.

Sudjana, Nana dan Rivai, Ahmad. (2002). Media Pengajaran. Bandung: Sinar Baru Algesindo.

Xia, X., Lü, C., Wang, B. (2008). "Research on Mathematics Instruction Experi-ment Based Problem Posing”. Journal of Mathematics Education. Vol. 1 (1), hal: 153-165. 